\title{
Mirosław Czapla
}

\section{Charakterystyka prawna niezdolności psychicznej do przyjęcia istotnych obowiązków małżeńskich służących jedności i prokreacji kan. 1095, n. 3 KPK)}

Ius Matrimoniale 7 (13), 45-65

2002

Artykuł został zdigitalizowany i opracowany do udostępnienia w internecie przez Muzeum Historii Polski w ramach prac podejmowanych na rzecz zapewnienia otwartego, powszechnego i trwałego dostępu do polskiego dorobku naukowego i kulturalnego. Artykuł jest umieszczony w kolekcji cyfrowej bazhum.muzhp.pl, gromadzącej zawartość polskich czasopism humanistycznych i społecznych.

Tekst jest udostępniony do wykorzystania w ramach dozwolonego użytku. 
Ius Matrimoniale

7 (13) 2002

\section{Ks. Mirosław Czapla}

\section{Charakterystyka prawna niezdolności psychicznej do przyjęcia istotnych obowiązków małżeńskich służących jedności i prokreacji (kan. 1095, $3^{\circ}$ KPK)}

W Kodeksie Jana Pawła II pojawil się nowy tytuł nieważności małżeństwa - kan. 1095, który normuje naturalną niezdolność osoby do wyrażenia ważnej zgody malżeńskiej'. Trzeci stopień owej normy kodeksowej określa niezdolność do przyjęcia istotnych obowiązków małżeńskich z przyczyn natury psychicznej. Celem tej charakterystyki jest refleksja nad szczególowymi postaciami owej niezdolności tj. do przyjęcia obowiązku jedności (wierności) i prokreacji (aktu małżeńskiego). Te bowiem istotne obowiązki małżeńskie chronią prawo osoby do pożycia intymnego. Po zarysowaniu pojęcia incapacitatis assumendi należy jego rozważanie zawęzić do sfery takich zaburzeń psychoseksualnych i osobowościowych, które uniezdalniają osobę do spełniania aktu małżeńskiego. Zarówno doktryna jak i jurysprudencja ukazują ten tytuł prawny jako normę dotyczącą rzeczywistości różnych perturbacji psychicznych, które mogą powodować niezdolność osoby do wyrażenia ważnej zgody małżeńskiej².

' Zdolność naturalną określają warunki osobowe podmiotu; w opinii M. F. Pompeddy, „kanon 1095 bierze pod uwagę trzy figury niezdolności naturalnej, pochodzacej z defektów psychicznych: stanowią one trzy motywy nieważności małżeństwa”(Kan. 1095 w systematyce generalnej KPK i w ewolucji interpretacyjnej. IusMatr 4:1999 s. 33).

${ }^{2}$ Wypada podać, choć ogólnie, niektóre artykuły poruszające tematykę niezdolności psychicznej normowanej zwlaszcza przez $3^{\circ}$ kan. 1095: M. J. Reinhardt. The Incidence of Mental Disorder. SCan 6:1972 s. 209-225; O. Fumagalli Carulli. Lincapacità psichica nella riforma del matrimonio canonico. JUS XXIII:3:1976 s. 222-262; P. Felici. De morbis psychicis quoad matrimonialem consensum. PRMCL 68:1979 s. 543-548; M. Lader. Valium and Associated Drugs which can Influence the Giving of True Matrimonial Consent. SCan 13:1979 s. 455-464; A. Stankiewicz. De accomodatione regulae „Impossibilium nulla obligatio est” ad incapacitatem adimplendi matrimoni obligationes. PRMCL 68:1979 s. 649-672; J. B. Zusy. Matrimonial Consent and Immaturity. SCan 15:1981 s. 199-239; A. Mendonca. Antisocial Personality and 
Prawodawca wprowadzając nowe pojęcie prawne precyzyjnie określił trzy jego człony: 1. Niezdolność do przyjęcia, 2. Istotne obowiązki małżeńskie, 3. Przyczyny natury psychicznej. „Niezdolność do przyjęcia istotnych obowiązków małżeńskich" oznacza niemożność przyjęcia przedmiotu zgody małżeńskiej. Słowo incapacitas wyraża ciężkość o charakterze absolutnym i niekwestionowanym ${ }^{3}$. Jednakże trzeba zaznaczyć, że w przypadku niezdolności pochodzącej $z$ dewiacji, ta ostatnia musi występować w takim natężeniu, które spowoduje całkowitą dezintegrację osobowości i uczyni osobę niezdolną do odpowiedzialnej decyzji na małżeństwo ${ }^{4}$. Dewiacja lub zaburzenie osobowości

Nullity of Marriage. SCan 15:1981 s. 45-72; L. Orsy. Matrimonial Consent in the new Code Glossae on Canons 1057, 1095-1103, 1107. Jur 43:1983 s. 29-68; M. F. Pompedda. De incapacitate adsumendi obligationes matrimonii essentiales. PRMCL 75:1986 s. 129-151; Tenże. Il canone 1095 del nuovo codice di diritto canonico tra elaborazione precodiciale e prospettive di sviluppo interpretativo. IusCan XXVII:54:1987 s. 535-555; F. Gil de las Heras. La incapcidad para asumir las obligationes esenciales del matrimonio (su tratamiento en los tribunales eclesiasticos espańoles). lusCan XXVII:53:1987 s. 253-290; I. Gramunt - L. A. Wauck. Capacity and Incapacity to Contract Marriage. SCan 22:1988 s. 147-168; A. Mendonca. The Role of Experts in „Incapacity to Contract" Cases (Canon 1095). SCan 25:1991 s. 417-450; Tenże. Consensual Incapacity for Marriage. Jur 54:1994 s. 477-559; T. A. Moran. Post-traumatic Stress Disorder, Broken Marriages, and the Appropriate Grounds of Nullity. Jur 54:1994 s. 183-204; M. P. Hilbert. Classificazione delle Patologie psichiche di tipo paranoide: analisi strutturale e giurisprudenza rotale di merito. PRMC 86:1997 s. 125-144; M. Fąka. Niezdolność do przyjęcia istotnych obowiązków małżeńskich jako tytul nieważności małżeństwa. PK 25:1982 s. 245-269; M. Al. Żurowski. Niezdolność do podjęcia obowiązków małżeńskich z przyczyn psychicznych. PK 29:1986 nr 3-4 s. 153-162; S. Kosowicz. Zaburzenia psychiczne ograniczające wykonanie zobowiązań powziętych w akcie zgody małżeńskiej. PK 29:1986 nr 1-2 s. 217-226; W. Góralski. Niezdolność do wypełnienia obowiązów małżeńskich jako tytuł nieważności małżeńskich. StPł 9:1981 s. 203221 ; Tenże. Zadania psychologa w sprawach o nieważność malżeństwa w świetle nowego prawa małżeńskiego. PK 29:1986 nr 3-4 s. 163-172; Tenże. Problem nieważności umowy małżeńskiej z tytułu niezdolności do podjęcia i wypełnienia zobowiązań małżeńskich. KiP T. IV. Lublin 1985 s. 189-211; Tenże. Nieważność małżeństwa z tytułu niezdolności psychicznej do podjęcia istotnych obowiązków małżeńskich. KiP T. VI. Lublin 1989 s. 69-75; Tenże. Niezdolność do podjęcia istotnych obowiązków malżeńskich. W: Przymierze małżeńskie. Lublin 1993 s. 31-48.

" "Gravis defectus discretionis iudicii" oznacza, że ma on być poważny wobec przedmiotu zgody małżeńskiej, czyli pozbawiony albo minimum wiedzy o małżeństwie, albo wystarczającej oceny krytycznej - proporcjonalnej do istotnych praw i obowiązków, albo wystarczającej wolności wewnętrznej. Jak stwierdza Góralski, gravitatis braku rozeznania oceniającego nie da się (...) ustalić w oparciu o kryteria medyczne, psychiatryczne i psychologiczne, gdyż w ten sposób do dziedziny prawniczej wprowadzałoby się pojęcie należące do innej dyscypliny"(Góralski. Niezdolność do zawarcia małzeństwa. Art cyt. s. 30).

${ }^{4}$ B. W. Zubert. Biseksualizm a zgoda małżeńska. W: Tożsamość seksualna nupturientów a zdohność do zgody małżeńskiej. Materiały I Międzynarodowego Sympozjum Prawa Kanonicznego - zorganizowanego przez Katedrę Prawa Kanonicznego Wydziału Teologicznego Uniwersytetu Opolskiego w Opolu 16.10.1996. Red. B. W. Zubert OFM. Opole 1998 s. 86. 
stanowią przyczynę takiej psychicznej niedyspozycji człowieka, której skutkiem jest niezdolność do ważnej zgody malżeńskiej.

Innym elementem ,niezdolności do przyjęcia” jest uprzedniość. Incapacitas assumendi określa lepiej niż incapacitas adimplendi moment uprzedniości sygnalizujący obecność niezdolności przed wyrażeniem zgody przez nupturientów. Aby móc obowiązki małżeńskie wypełnić trzeba je wcześniej przyjąć. ${ }^{5}$ Wprawdzie do nieważności małżeństwa jest konieczna jedynie wadliwość zgody w chwili zawierania przymierza sakramentalnego ${ }^{6}$, niemniej doktryna i judykatura kładą nacisk na uprzedni charakter incapacitatis. Wymóg ten może być dyktowany racjami procesowymi lub moźliwościami dowodowymi. Wedle M. Pompeddy, uprzedniość nie jest koniecznym elementem incapacitatis, gdyż wystarczy, by ona istniała w małżeństwie in statu fieri ${ }^{7}$.

Trwałość nie jest elementem wymaganym do uznania „niezdolności do przyjęcia" za wadę zgody. Incapacitas assumendi powinna bowiem występować w chwili zawierania małżeństwa, by móc uznać je za nieważne. Gdy w przymierzu małżeńskim miała miejsce wada konsensu, wówczas z punktu widzenia kanonicznego trwałość - nieusuwalność tej niezdolności nie ma już znaczenia. Wszakże prawdziwa niezdolność jest ze swej natury trwała ${ }^{8}$. Problem jednak wydaje się bardziej złożony ze względu na różną naturę istotnych obowiązków małżeń-

\footnotetext{
" W. Góralski. Nieważność małżeństwa z tytułu niezdolności psychicznej do podjęcia istotnych obowiązków małżeńskich. KiP 6:1989. Art. cyt. s. 72.

"J. H. Provost stwierdza, iż jeśli przyczyny powstają po wyrażeniu zgody, wówczas będąca ich rezultatem niezdolność nie dotyka ważności zgody. Kanonista podaje interesujący przykład związany z niezdolnością do podjęcia pożycia intymnego: „An example might be the difference between a soldier who married before goinig overseas, and returned a notably changed person because of battlefield experience; and the soldier who was engaged before going overseas, was changed by the battlefield experience; but married shortly upon returning home. In the letter case, the psychic cause was present at the time of the marriage; in the former one, it was not" (Canon 1095: Past, Present, Future. Jur 54:1994 s. 100).

${ }^{7}$ Pompedda. Kan. 1095. Art. cyt. s. 42.

${ }^{8}$ Góralski. Niezdolność do zawarcia małżeństwa. Art. cyt. s. 33; Tenże. Czy „incapacitas assumendi" (kan. 1095 n. 3 KPK) powinna być trwala? PK 37:1994 nr 3-4 s. 247-257; podobnie uważa T. Pawluk. (Prawo kanoniczne wedhug Kodeksı Jana Pawla II. T.III. Prawo malżeńskie. Olsztyn 1984 s. 159) oraz M. Al.Żurowski który akcentuje jednak wymóg trwałości, gdyż przy niezdolności do przyjęcia istotnych obowiązków małżeńskich „nie można brać pod uwagę chwilowej niedyspozycji, lecz musi być ta niezdolność do wykonania czymś stałym, nieusuwalnym zwykłymi środkami dostępnymi dla przeciętnego czlowieka" (Kanoniczne prawo małżeńskie Kościoła katolickiego. Katowice 1987 s. 232). Trudno wszak zaprzeczyć, że do nieważności małżeństwa wystarczy jedynie wada zgody, czyli niezdolność osoby w chwili zawierania małżeństwa.
} 
skich. Wedle niektórych istotą wymagania trwałości jest natura konkretnego obowiązku". Wedle Pompeddy, taką istotą jest jeszcze natura stanu życia małżeńskiego ${ }^{10}$ a pojęciami niezdolności z dwu wcześniejszych numerów kan. 1095 małżeńskich"1!

Przedmiotem niezdolności psychicznej z kan. $1095,3^{\circ}$ są , istotne obowiązki malżeńskie". Zakres tego wyrażenia można ująć w siatce czterech pojęć - celów i przymiotów małżeńskiego przymierza, ponieważ stanowią one źródło praw i obowiązków w małżeństwie (kan. $10551 \mathrm{i}$ 1056). Powszechnie przyjęta doktryna kanonistyczna uznaje bowiem cztery rodzaje dóbr malżeńskich za fundament do precyzacji konkretnych zobowiązań' ${ }^{2}$. Wypada zatem ogólnie stwierdzić, że dobro malżonków, dzieci, wiary i sakramentu stanowią źródło istotnych obowiązków małzeńskich. Te ostatnie służą realizacji celów i przymiotów malżeństwa ${ }^{13}$.

\footnotetext{
"Por. P. A. Pavanello. Il requisito della perpetuità nell'incapacità di assumere le obbligazioni essenziali del matrimonio (Can. 1095, $3^{\circ}$ ). Roma 1994 s. 121-122; E. Egan. The Nullity of Marriage for reason of Incapacity to Fullfill the Essential Obligations of Marriage. EIC 40:1984 s. 30; E. Olivares. Incapacitas assumendi obligationes essentiales matrimonii, debetne esse „perpetua”? PRMCL 75:1986 s. 155; A. Mendona. The Theological and Juridical Aspects of Marriage. SCan 22:1988 s. 302-303.

In Por. RRDec. c. Pompedda 19.10.1990 nr 9. IusEc 4:1992 s. 159.

"Góralski. Kanoniczna zgoda małżeńska. Dz. cyt. s. 84-85. Żurowski ujmuje to następująco: „Jeśliby (...) rozeznanie istotnych uprawnień i przedmiotu zgody malżeńskiej, nawet jej wyrażenie było poprawne, a istniałby obiektywny brak zdolności, zgoda taka będzie bezprzedmiotowa a akt pusty" (Kanoniczne prawo małżeńskie. Dz. cyt. s. 233).

"Zurowski. Dz. cyt. s. 234.

${ }^{13} \mathrm{R}$. Sztychmiler wymienia obowiązki ,służące przede wszystkim realizacji dobra małżonków":

1. Obowiązek zachowania wierności (wyłączności) małżeńskiej.

2. Obowiązek ludzkiego (humano modo) pożycia intymnego ze współmalżonkiem

3. Obowiązek nierozerwalności, czyli zachowania dozgonnego charakteru małżeństwa

4. Obowiązek pielęgnowania wspólnoty życia małżeńskiego, czyli prawidłowych małżeńskich relacji interpersonalnych

5. Obowiązek świadczenia współmałżonkowi pomocy

6. Obowiązek przyczyniania się do dobra wspótmatżonka

7. Obowiązek świętości

Dalszą kategorię stanowią „obowiązki związane z wychowaniem dzieci”:

1. Obowiązek pożycia intymnego zmierzającego do zrodzenia potomstwa

2. Obowiązek przyjęcia potomstwa poczętego ze wspólmałżonkiem

Wreszcie ostatnią kategorię stanowią „Obowiązki związane z wychowaniem dzieci”:

1. Obowiazek wychowania ogólnoludzkiego

2. Obowiązek fizycznego wychowania potomstwa

3. Obowiązek wychowania religijnego (Istotne obowiązki malżeńskie. Warszawa 1997 s. 244-254).
} 
Przyczyny psychiczne są czynnikiem sprawczym niezdolności osoby do przyjęcia przedmiotu zgody małżeńskiej. Pod tym pojęciem rozumie się zaburzenia ludzkiej psychiki powodujące niepokonalne ograni* czenia osoby wobec możliwości realizacji zobowiązań małżeńskich. Zaburzenia te wciąż pozostają trudne do zbadania i usystematyzowania, gdyż dotyczą sfery znacznie bardziej skomplikowanej niż zaburzenia fizjologiczne, nawet $w$ aspekcie neurologicznym. Dla kanonistyki niezdolność psychiczna do przyjęcia istotnych obowiązków małżeńskich wydaje się trudniejszym tytułem nieważności od braku wystarczającego używania rozumu i poważnego braku rozeznania oceniającego właśnie ze względu na zaburzenia natury emocjonalnej i wolitywnej, a nie intelektualnej ${ }^{14}$. Termin ,przyczyny natury psychicznej” zastosowany w kan. $1095,3^{\circ}$ ma charakter ścisły, tzn. nie dotyczy wszystkich zaburzeń związanych z psychiką człowieka (np, niedojrzalości afektywnej, obsesji czy myśli natrętnych, poważnej bojaźni wewnętrznej, psychozy depresyjno-maniakalnej, fanatyzmu czy innych $)^{15}$, lecz obejmuje stany patologiczne przyporzadkowane sferze psychoseksualnej i osobowościowej.

2.1. Przyczyny niezdolności psychicznej do przyjęcia obowiązku aktu małżeńskiego

Pojęcie niezdolności do przyjęcia istotnych obowiązków małżeńskich z przyczyn natury psychicznej zostało przedstawione w ogólnym ujęciu; obecnie wypada podjąć szczególową refleksję nad tą niezdolnością w kontekście aktu małżeńskiego. Przedmiot badania należy zatem zawęzić do tego zakresu niezdolności, który dotyczy zobowiązania do pożycia intymnego w małżeństwie.

Wśród czynników sprawczych określonego powyżej zakresu niezdolności najczęściej mówi się o zaburzeniach psychoseksualnych. Już sama obecność takich zaburzeń wzbudza wątpliwość, czy osoba będzie

\footnotetext{
${ }^{14}$ F. Bersini ujmuje to krótko: „In altri termini, mentre il numero precedente riguarda prevalentemente il fattore intellettivo in quanto tale, questo numero riguarda la patologia latente e l'immaturità psichica che si riferiscono sopratutto alla sfera molto pi complicata affettivo-volitiva della personalit"(It diritto canonico matrimoniale. Commento giuridico-teslogico-pastorale. Torino 1994 s. 98).

is Zurowski. Dz. cyt. s. 229; Gerosa. Dz. cyt. s. 283.
} 
w stanie przyiąc istotne zobowiązanie małżeńskie do pożycia intymnego. Podkreśla się jednak, że niezdolność powodować mogą zaburzenia w stopniu poważnym ${ }^{16}$. Postaciami zaś patologii psychoseksualnych generujących incapacitas assumendi w kontekście prawa/obowiązku do aktu małżeńskiego, są zwykle homoseksualizm, nimfomania, satyryzm czy transseksualizm ${ }^{17}$.

\subsubsection{Homoseksualizm}

Homoseksualizm stanowi ważki problem społeczny, a jako taki stanowić też musi zagadnienie sądowe i pastoralne ${ }^{18}$. W doktrynie i jurysprudencji zaznaczyla się znacząca zmiana w odniesieniu do homoseksualizmu ${ }^{19}$. Zwieńczeniem posoborowej ewolucji orzecznic-

${ }^{16}$ J.M. Gonzalez del Valle. Derecho canonico matrimonial segn Cdigo de 1983. Pamplona 1991 s. 160.

${ }^{17}$ F. R. Aznar Gil. El Nuevo Derecho Matrimonial Cannico. Salamanca 1985 s. 331.

1s Opracowania tego zagadnienia od strony sądowej i duszpasterskiej podjął się W. Szafrański w swej monografii: „Homoseksualizm jako problem Pastoralno-Sądowy”, gdzie w sposób systematyczny zaprezentował aspekt biologiczny schorzenia oraz jego aspekt religijny (Wloclawek 1987). Kongregacja Nauki Wiary podała wskazania duszpasterskie w odniesieniu do osób homoseksualnych m.in. $w$ dokumentach: „Deklaracja o niektórych zagadnieniach etyki seksualnej (Persona humana)”, „List do Biskupów Kościola katolickiego o duszpasterstwie osób homoseksualnych (Homosexualitas problema)” oraz „Uwagi dotyczące odpowiedzi na propozycje ustaw o niedoskryminacji osób homoseksualnych (Omosessualità)”. Ściśle pastoralny charakter posiada praca D. Ange'a „Homoseksualizm. Czym jest? Do czego prowadzi?” (Kraków 1993), zaś monografia G. Van Den Aardweg „Homoseksualizm i nadzieja" stanowi psychologiczne opracowanie problemu. Jest to praca niezwykle cenna, gdyż sprzeciwia się modnej dziś tendencji psychologicznej, prawnej, a nawet pastoralnej, do uznawania homoseksualizmu za problem zdeterminowany genetycznie i nieuleczalny (Warszawa 1999).

${ }^{19}$ Przed Soborem Watykańskim II nie traktowano homoseksualizmu w odniesieniu osobowym do wspólmałżonka; w CIC/1917 sprawy homoseksualistów prowadzono z różnych tytułów uznając za podstawę anomalii impotencję (traktując dewiację za objaw impotencji psychicznej), albo całkowitą lub częściową chorobę umysłową (amentia, dementia), albo nienormalność w sprawach małżeńskich (insania circa rem uxoriam) albo symulację częściową. Dopiero wyrokiem c. Lefebvre z 2.12.1967 jurysprudencja podniosła problem postrzegania homoseksualizmu z poziomu porządku prokreatywnego na poziom zaburzeń osobowości; orzeczono tam nieważność malżeństwa homoseksualisty z powodu braku rozeznania oceniającego oraz niezdolności do przyjęcia obowiązków małżeńskich. Homoseksualizm bowiem wywoławszy niepokonalną awersję do płci przeciwnej uniemożliwił przekazanie i przyjęcie prawa do ciała, zmierzającego do aktów małżeńskich zdatnych z siebie do zrodzenia potomstwa (W. Góralski. Homoseksualizm a zdolność do małżeństwa. W: Tożsamość seksualna nupturientów a zdolność do zgody małżeńskiej. Dz. cyt. s. 55-57). 
twa rotalnego w odniesieniu do homoseksualizmu jest wykluczenie od zawarcia malżeństwa osób niezdolnych do podjęcia istotnych obowiązków małżenskich. Człowiek dotknięty homoseksualizmem nie jest bowiem zdolny do pelnego daru $z$ siebie i partnerstwa we wspólnocie malżeńskiej, gdyż nie jest w stanie nawiązać ze współmałżonkiem relacji międzyosobowych, esencjalnych dla wspólnoty życia małżeńskiego ${ }^{20}$.

Przekazanie i przyjęcie prawa do aktów intymnych ze swej natury zdolnych do zrodzenia potomstwa nie może być rozumiane jedynie w aspekcie fizycznym (ius in corpus exclusivum et perpetuum), lecz w kontekście głębokiej intymnej wspólnoty osób. Nie mogąc przekazać samego siebie - własnej osoby - jako przedmiotu zgody małżeńskiej wraz ze wszystkimi prawami i obowiązkami, człowiek dotkniety homoseksualizmem nie jest w stanie wyrazić ważnego konsensu. W opinii W. Góralskiego, brakuje w takim przypadku istotnego przymiotu, niezbędnego do przymierza małzeńskiego, którym jest „wystarczająca normalność w sprawach seksualnych". Bez tej normalności człowiek może być zdolny do copulatio carnalis perficiendi, lecz „psychologicznie przejawia brak zdolności do powzięcia zgody mał̇zeńskiej, gdyż dotknięty jest prawdziwą anomalią"21.

Jednoznaczne i aprioryczne wskazanie obowiązków małżenskich, jakie nie moga zostać przekazane w akcie przymierza matrymonialnego, zawieranego przez konkretnego homoseksualiste, wydaje się stanowić dużą trudność. W opinii G. Erlebacha ,taki stan rzeczy jest (...) uwarunkowany możliwością zróżnicowania wpływu homoseksualizmu na poszczególne osoby, które są nim dotknięte. Stąd to samo zaburzenie może powodować wyakcentowanie tej lub innej formy nie-

\footnotetext{
${ }^{20}$ Gonzalez del Valle. Derecho canonico matrimonial. Dz. cyt. s. 160; P. G. Bianchi. Incapacitas assumendi obligationes essentiales matrimonii. Analisi della giurisprudenza rotale, particolarmente degli anni 1970-1982. Milano 1992. s. 195; I. Fuek. Omosessuali nel celibato e nel matrimonio: alcuni casi. PRMC 83:1994 s. 290-291 [273-291]; G. Ghirlanda. Il diritto nella Chiesa mistero di comunione. Compendio di diritto ecclesiale. Roma 1993 s. 356-357; por. P. K. Thomas. Marriage annulment for gay Men and lesbian Women new canonical and psychological Insights. Jur 43:1983 s. 319-325.

${ }^{21}$ Autor powoluje się na wyrok c. Pinto z 14.04.1975, gdzie stwierdzono: „Quodsi, matrimoniali consensu praestito, ob gravem anomaliam psycho-sexualem momento celebrationis existentem, contrahens praefatas obligationes consensu assumptas adimplendi incapax fuerit, matrimonium ex natura rei invalidum erit, ob illius inhabilitatem ad obiectum formale essentiale contractus praestandum"(Homoseksualizm a zdolność. Art. cyt. s. 60$)$.
} 
zdolności u danego nupturienta"'?2. Przeto każdy przypadek homoseksualizmu musi byc rozpatrywany osobno celem rozeznania jakiego rodzaju dobro małżeńskie nie może zostać zrealizowane wskutek niezdolności psychicznej. Mimo to, można wyrazić pogląd, że o ile nie zawsze osoba homoseksualna bylaby niezdolna do przekazania i realizacji obowiązku aktu intymnego w małżeństwie, o tyle zawsze pozostaje niezdolna przekazać obowiązek wierności ${ }^{23}$.

Warunkami uznania tej patologii za psychiczną przyczynę niezdolności są ciężkość i uprzedniość. Trwalość wydaje się nie stanowić takiego warunku; istotne i ważne jest przecież, by dewiacja występowala w chwili zawierania związku małżeńskiego ${ }^{24}$. Homoseksualizm w formie ciężkiej rozumiany jest jako prawdziwy, tj. stanowiący patologię sfery psychoseksualnej. Przejściowe i jedynie okazjonalne akty homoseksualne nie są bowiem w kanonistyce uznawane za ciężką formę tej dewiacji25. Uprzedniość homoseksualizmu dotyczy także jego formy ukrytej, która została ujawniona po zawarciu przymierza małżeńskiego.

\subsubsection{Transseksualizm}

Natrętne pragnienie przynależności do przeciwnej plci jest istotą zaburzenia tożsamości seksualnej zwaną transseksualizmem. Stąd

\footnotetext{
${ }^{22} \mathrm{G}$. Erlebach. Tożsamość seksualna a nieważność związku małżeńskiego według najnowszej jurysprudencji rotalnej (1983-1994). W: Tożsamość seksualna nupturientów a zdolność do zgody małżeńskiej. Dz. cyt. s. 155.

${ }^{23}$ Por. dec. c. Corso 14.04 .1988 n. 4 (niepublikowany - nr 61/88); dec. c. Serrano Ruiz 6.05.1987. RRD 79:1987 s. 268-284; dec. c. Pompedda 19.10.1992. RRD 84:1992 nr 11s. 497.

${ }^{24} \mathrm{~W}$ wyroku c. Lefebvre z 2.12.1967 wyrażono opinię o konieczności schorzenia w czasie malżeństwa ,in statu fieri”: „Ne haec moralis impotentia ad obiectum consensus requiritur perpetua, cum ipsum obiectum revera evanescat tempore celebrationis contractus"(SRRDec. vol. 59:1967 s. 804); Szafrański twierdzi, że „owa niezdolność nie musi być trwała, ponieważ przedmiot zgody małżeńskiej nie istnieje w chwili jej wyrażenia" (Homoseksualizm jako problem. Dz. cyt. s. 139) Innego zdania wydaje się być J. Huber, który stwierdza, że wtedy, gdy skłonność homoseksualna osoby wobec wszystkich osób płci przeciwnej, jest trwała, wówczas małżeństwo jest nieważne; wszakże w takim przypadku osoby dotknięte homoseksualizmem „cierpią na impotencję w rozumieniu kan. 1084 1" (Transseksualizm i transwestytyzm. W: Tożsamość seksualna nupturientów a zdolność do zgody malżeńskiej. Dz. cyt. s. 50).

${ }^{25}$ Przez homosekstzalizm ciężki, czyli prawdziwy należy rozumieć „stalą tendencję i postępowanie (ratio agendi) związane $z$ nieprzezwyciężalnym skierowaniem popędu płciowego wyłącznie lub prawie wyłącznie do osób tej samej płci, mające swoje źródło bądź w stałej i długotrwalej dyspozycji nabytej (...), bądź w samej konstytucji osoby"(Góralski. Homoseksualizm a zdolność. Art. cyt. s. 61).
} 
powszechnie uważa się, że transseksualizm jest anomalią ujawniającą się w sferze psychoseksualnej, nie zaś fizjologicznej czy anatomicznej. Ta ostatnia nie jest bowiem zniekształcona - przeciwnie prawie zawsze funkcjonuje normalnie ${ }^{26}$. Chociaż płeć jest zdeterminowana w sposób biologiczny (genetycznie, chromosomalnie, gonadalnie i fenotypowo) dana osoba czuje się psychicznie przynależna do innej płci, brzydząc się swych genitaliów $w^{27}$. Jak zaznacza J. Huber, osoba taka „myśli inaczej, czuje inaczej, doznaje inaczej, aniżeli wskazuje na to cialo"28. Ten bardzo zlożony problem psychiatryczny i spoleczny wymaga szczególnej dokładności i jasności w badaniu teologiczno-prawnym. Jakkolwiek w kwestii transseksualizmu teologia moralna określa swoje stanowisko jednoznacznie ${ }^{29}$, przyznać należy, iż kanonistyka dopiero zainicjowała swe poszukiwania ${ }^{30}$. Opie-

${ }^{26}$ Por. K. Imieliński - S. Dulko - M. Filar. Transpozycje plci. Transseksualizm i inne zaburzenia identyfikacji płciowej. Warszawa 1997 s. 116.

${ }^{27}$ P. G. Bianchi. Incapacitas assumendi obligationes. Dz. cyt. s. 202.

${ }^{33}$ Autor poddaje analizie medycznej i kanonistycznej osoby dotknięte tą anomalią. Warto przytoczyć rozumienie pewnych pojęć medycznych: pleć chromosomalna (genetyczna) $=$ pleć określona podezas zapłodnienia, pleć gonadalna $=$ płeć określona przez dojrzewające gruczoly plciowe (gonady), pleć fenotypowa (genitalna) = płeć określona przez rozwijające się cechy plciowe; cenna jest też prezentacja krótkiej charakterystyki osób transseksualnych: „Osoba transseksualna ma inne niż oczekiwane wyobrażenie o swojej tożsamości (...) idealizuje płeć, do ktôrej czuje się psychicznie przynależna i usilnie, niejako pod przymusem, dąży do zmiany swoich organów płciowych, swej cielesnej powłoki i socjalnej pozycji. Szczególnie intensywne jest owo dążenie u transseksualnych mężczyzn, dla których męskie genitalia są coraz bardziej nieznośną udręką. Odczuwają je jako niebezpieczeństwo i zagrożenie. Nierzadko dochodzi u nich do odpowiednich samookaleczeń i ustawicznie pragną operacyjnej korekty, która miałaby na celu utworzenie żeńskich genitaliów (Transseksualizm i transwestytyzm. Art. cyt. s. 34-35).

${ }^{20} \mathrm{Z}$ punktu widzenia moralnego nie budzą żadnych zastrzeżeń dzialania terapeutyczne polegające na psychologicznym lub hormonalnym oddzialywaniu na ośrodki płci psychicznej. Są one jednak mało skuteczne (por. K. Imieliński - S. Dulko. Przekleństwo Androgyne. Transseksualizm: mity i rzeczywistość. Warszawa 1988 s. 257-258). Operacja chirurgicznej zmiany pici jest zaś zabiegiem niemoralnym, gdyż pozostając bez wewnętrznego związku $z$ chorobą nie jest zabiegiem leczniczym (por. J. Wróbel. Czlowiek i medycyna. Teologicznomoralne podstawy ingerencji medycznych. Kraków 1999 s. 382-387).

3it Por. U. Navarrete. Transsexualismus et ordo canonicus. PRMC 86:1997 s. 101-124; C.J. Ritty. The Transsexual and the Marriage. SCan 15:1981 s. 441-459; J.J. Graham. Transsexualism and the Capacity to Enter Marriage. Jur 41: 1981 s. 117-154; A. Dzięga. Co to jest transseksualizm? IusMatr T. 3. Lublin 1992 s. 50-53; tenże. Wplyw transseksualizmu na zdolność osoby do zawarcia małżeństwa. Uwagi i pytania. W: Kościelne Prawo Procesowe. Materiały i Studia. T. I. Lublin 1999 s. 137-150. Jakkolwiek istnieje jednoznaczna opinia Kongregacji Nauki Wiary (pismo KNW z 28.05.1991 opublikowane w: De processibus matrimonialibus 2:1995 s. 315) to wydaje się, że klasyfikacja doktrynalna zagadnienia w kanonistyce nie znalazla jeszcze należytego przełożenia praktycznego. Przykładem może być 
rając się jednak na opinii Hubera, można ustosunkować się do problemu szczególowego, tj. dopuszczenia transseksualistów do zawarcia malżeństwa.

Małzeństwo osoby, która zmieniła pleć przed zawarciem małżenskiego przymierza, z różnych przyczyn jest nieważne. Według J. Hubera, pierwszą z przyczyn jest brak zróżnicowania płciowego, drugą impotencja organiczna, trzecią zaś - brak psychicznej równowagi. Ow trzeci motyw nieważności takiego małżeństwa wynika ze znacznych zakłóceń harmonii pomiędzy anatomiczną a psychiczną płcią osoby transseksualnej. To głębokie zaburzenie równowagi czyni osobę niezdolną do zgody, niezależnie od etiologii samego zaburzenia. Zbliżoną systematykę możliwych tytułów niezdolności przedstawił P. G. Bianchi. Według niego, małżeństwo osoby transseksualnej jest nieważne wskutek braku seksualnej dyspozycyjności o charakterze trwałym, niezdolności do pożycia humano modo oraz niezdolności do „roli rodzicielskiej właściwej dla płci przynależności"31. Psychiczne zakłócenia sprawiają, że osoba taka nie jest w stanie przyjąć i przekazać istotnych praw i obowiązków małżeńskich. Wedle J. Hubera, dzieje się tak, gdyż „ze względu na swe psychiczne zaburzenia osoba transseksualna jest niezdolna do założenia wraz z partnerem "wspólnoty calego życia" i stworzenia prawdziwie interpersonalnych stosunków"32. Zdaniem A. Dzięgi, „transseksualista nie jest w stanie przyjąć i przekazać na zawsze prawa do ciała, mimo że fizycznie może być zdolny w pewien sposób do podejmowania aktów małżeńskich"33.

Trzeba zaznaczyć, że w jurysprudencji rotalnej, jak dotąd nie jest znany jakikolwiek wyrok, w którym z tytułu transseksualizmu zaskarżono by nieważność małżeństwa. Stwierdzenie nieważności zaś nie mogłoby opierać się na samym fakcie anomalii transseksualnej, lecz na „wystarczająco silnej konsystencji tej anomalii i zarazem niemożliwości kontrolowania własnej dążności do identyfikacji z plcią przeciwną" ${ }^{34}$. Wypada również zasygnalizować, że czymś całkowicie różnym jest możliwość zawarcia małżeństwa sakramentalnego od możliwości

opinia ks. prof. dr. hab. R. Sobańskiego o możliwościach zawarcia małżeństwa przez transseksualistów (ale jedynie mężczyzn, którzy dokonali operacji zmiany plci na żeńską), wyrażona w wywiadzie prasowym (Tygodnik Powszechny nr $50 \mathrm{z}$ 13.12.1998 s. 10).

${ }^{31}$ Incapacitas assumendi obligationes. Dz. cyt. s. 206-207.

${ }^{32}$ Transseksualizm i transwestytyzm. Art. cyt. s. 38-40.

${ }^{33}$ Wplyw transseksualizmu na zdolność osoby. Art. cyt. s. 145.

${ }^{34}$ Erlebach. Tożsamość seksualna. Art. cyt. s. 120-130. 
wieloletniego wspólnego zamieszkania osób transseksualnych po przebytej operacji zmiany plci35.

\subsubsection{Zaburzenia osobowości}

Patologia osobowości może być kolejnym źródłem zaburzeń, które czynią osobę niezdolną do przyjęcia obowiązku aktu małżeńskiego. Poważne perturbacje psychiczne mogą przyczynić się do powstania w osobie zahamowania uniemożliwiającego podjęcie pożycia intymnego. Zaburzenia osobowości odbierają nupturientowi zdatność do nawiązania relacji międzyosobowych $w$ małżenstwie. W szerokiej typologii pojęcia „osobowość zaburzona” odnaleźć można rodzaj osobowości nazwany „osobowością histrioniczną (histeryczną)". Przypadki takiej osobowości zdają się potwierdzać powyższą tezę. Zaburzenia histrioniczne nie tylko uniemożliwiają powstanie relacji międzyosobowych, lecz także mogą uniezdolnić osobę nawet do aktu małżeńskiego, który wszakże wyraża osobowy wymiar ludzkiej seksualności. Ogólny infantylizm oraz „uwodzicielskość w dziedzinie seksualnej", zwłaszcza u mężczyzn, udaremniaja już to duchowe, już to fizyczne połączenie się z małżeńskim partnerem³

\subsection{Przyczyny niezdolności psychicznej do przyjęcia obowiązku wierności małżeńskiej}

Obowiązek wierności stanowi jedno z podstawowych zobowiązań malżeńskich, podejmowanych przez osobę w sakramentalnym przymierzu. Ochrona wyłącznego prawa do pożycia intymnego w kontekście osobowych relacji jednego mężczyzny i jednej kobiety ma ogromne znaczenie dla wlaściwego rozwoju ,wspólnoty całego życia”. Dlatego też każda okoliczność powodująca psychiczną niezdolność osoby do przyjęcia obowiązku wierności ${ }^{37}$ może być równocześnie uznana za przyczynę nieważności malżeństwa.

\footnotetext{
${ }^{35}$ Dzięga. Wplyw transseksualizmu na zdolność osoby. Art. cyt. s. 146.

${ }^{*}$ S. Paździor przytacza przykład mężczyzny, który „w trakcie małżeństwa przejawial zachowania histeryczne, popadając $z$ jednej skrajności w drugą. Nie utrzymywal z żoną kontaktów cielesnych, nie wykazywal w tym względzie chęci współżycia. Jak potwierdził biegły seksuolog, nie było to spowodowane impotencją" (Przyczyny psychiczne. Dz. cyt. s. 112).

${ }^{37}$ L. G. Wrenn. Canon 1095: A Bird's-eye view. Jur 44:1984 s. 240.
} 


\subsubsection{Nimfomania i satyryzm}

Nadmierny popęd seksualny kobiety, który sprawia, że szuka ona zaspokojenia także poza małżeństwem, stanowi inny poważny defekt psychoseksualny, zwany nimfomanią. Powoduje ona niezdolność osoby do przyjęcia przedmiotu zgody małżeńskiej. ${ }^{38}$. Męską anomalią psychoseksualną, będącą odpowiednikiem nimfomanii jest satyryzm. Mężczyzna dotknięty tą dewiacją odczuwa niekontrolowaną potrzebę spełniania aktów seksualnych, która przybiera w jego mentalności formy obsesyjne. Obie te formy stanowią zatem taką psychopatologię osoby, która w kanonistyce nazywana jest hiperseksualizmem lub hiperseksualnością̧ą.

Często satyryzm lub nimfomania są tak rozwinięte, że człowiek nie jest w stanie nad nimi panować. Jak pisze Żurowski, „,czlowiek nie potrafi odeprzeć powstających pożądań, a tym samym nie może zobowiązać się do zachowania wierności. Nienasycone bowiem dążenie do zaspokojenia seksualnego skierowuje się do jakiejkolwiek osoby uniemożliwiając $z$ racji perwersji seksualnej przyjęcie zobowiązań, które

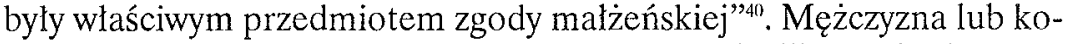
bieta dotknięci anomalią hiperseksualizmu w chwili wyrażania przymierza małżeńskiego mogą zawierać je nieważnie. W praktyce jurysprudencji zaskarżano później takie malżeństwo jako nieważne $z$ tytułu symulacji częściowej, szczególnie wykluczenia wierności małżenskiej (exclusio boni fidei $)^{41}$.

Trzeba jednak wyraźnie stwierdzić, że zarówno męska jak i żeńska postać hiperseksualizmu czynią osobę niezdolną do przyjęcia i przekazania prawa do aktów intymnych na stałe, czyli do wierności dozgonnej ${ }^{42}$. Dlatego nimfomania i satyryzm jako anomalie psycho-

${ }_{38}$ Vitali - BerlingÀ. Il matrimonio canonico. Dz. cyt. s. 83; G. Lanfaloni. Il matrimonio religioso. Cinisello Balsamo 1998 s. 34; G. Erlebach. Tożsamość seksualna. Art. cyt. s. 155-156; P. G. Bianchi. Incapacitas assumendi obligationes. Dz. cyt. s. 179-181; por. RRDec. c. Pinto z 4.02.1974 nr 5. ME 100:1975 s. 110.

${ }^{3}$ P. G. Bianchi. Incapacitas assumendi obligationes. Dz. cyt. s. 180; G. Erlebach. Tożsamość seksualna. Art. cyt. s. 124;

لII M. Al. Żurowski. Przedmiot zgody małżeńskiej i zdolności do wypelnienia obowiązków w ocenie umysłu poprzedzającej rozważną decyzję nupturienta. PK 26:198.3 nr 1-2 s. 277.

* Dec. c. Ferraro z 16.10.1984. RRD 76:1984 s. 519-532; dec. c. De Lanversin z 24.07.1985. RRD 77:1985 s. 415-425; dec. c. Stankiewicz z 26.03.1987. RRD 79:1987 s. $142-152$.

${ }^{\prime 2}$ P. G. Bianchi. Incapacitas assumendi obligationes. Dz. cyt. s. 185. 
seksualne przeciwne wierności są zwykle zaskarżane $z$ innych tytułów malżeńskich ${ }^{43}$.

\subsubsection{Transwestytyzm i pseudotranswestytyzm}

Inna patologia życia seksualnego, która może być przyczyną nieważności małżeństwa, nosi nazwę transwestytyzmu. Osoba dotknięta tym schorzeniem nosi w sobie pragnienie noszenia ubrań płci przeciwnej, gdyż w takim stroju odnajduje ona równowagę afektywną. Problem ten wydaje się dotyczyć głównie mężczyzn ${ }^{44}$. Transwestyta zdaje sobie sprawę z przynależności do określonej płci i wcale nie pragnie jej anatomicznej zmiany, ponieważ nie cierpi $z$ powodu wewnętrznego napięcia. Mimo to, lubi zachowywać się jak osoby płci przeciwnej i chce $w$ tej roli być uznawany przez środowisko. Podłoże psychiczne takich jego zachowań nie jest jeszcze dobrze znane ${ }^{45}$.

Osoby dotknięte transwestytyzmem ze swej natury są zdolne do malżeństwa, jako że dysponują zdolnością do przyjęcia praw i obowiązków małżeńskich. W opinii J. Hubera, wielu $z$ nich jest szczęśliwie żonatych. Dzieje się tak, ponieważ ,żona często toleruje zachowanie męża i pozwala mu chodzić w mieszkaniu w spódnicy". Badania naukowe wykazują jednakowoż, iż $21 \%$ kobiet nie akceptuje transwestytyzmu ${ }^{46}$.

${ }^{43}$ Dec. c. Davino z 10.01.1985. RRD 77:1985 s. 1-10; dec. c. Stankiewicz z 14.11.1985. RRD 77:1985 s. 485-494; dec. c. Huot z 2.10.1986. RRD 78:1986 s. 498-509; dec. c. Pinto z 20.02.1987. JusEc 1:1989 s. 569-579; dec. c. Giannecchini z 20.12.1988. ME 114:1989 s. 439 449; dec. c. Stankiewicz z 21.06.1990. RRD 82:1990 s. 523-534; dec. c. Burke z 13.06.1991. RRD 83:1991 s. 414; dec. c. Giannecchini z 21.02.1995. RRD 87:1995.

${ }^{4}$ P. G. Bianchi. Incapacitas assumendi obligationes. Dz. cyt. s. 200.

${ }^{45}$ Huber charakteryzuje pochodzenie omawianego schorzenia w sposób następują. cy: „Etiologia transwestytyzmu nie jest jasna. Prawdopodobnie większość przypadków bierze swój początek w wychowaniu rodzinnym, wskutek którego nie mogła nastạpić identyfikacja z rodzicem tej samej plci bądź z winy tegoż rodzica, bądź drugiego, albo też $z$ winy obydwu. Transwestyta już $w$ dzieciństwie preferowal ubrania - najczęściej bieliznę, zabawki, uczesanie, sposób wyrażania się, przeróżne upodobania, jak równiç możliwości zawodowe innej płci, ponieważ jedno albo też obydwoje rodzice życzyli so. bie dziecka innej płci. Nierzadko także pacjenci mówią swoim psychiatrom: dorastalem po śmierci mego ojca $z$ matką, ciotką i babką i te kobiety wychowaly mnie jak kobietę, nauczyły mnie odczuwać tak jak one" (Transseksualizm i transwestytyzm. Aré. cyt. s. 43-44).

"Wobec braku zgody żony na chodzenie w spódnicy po mieszkaniu u mężczyzny dotknię ‘tego transwestytyzmem mogą „wystąpić bóle żołądka, bóle kręgoslupa w okolicy krzyżowei, 
Gdy zaburzenia osobowości konkretnego transwestyty są tak duże, iż tylko w żeńskim stroju odnajduje on równowagę afektywną, wtedy jest on niezdolny do ważnego zawarcia małżeństwa.

Jakkolwiek wedle P. G. Bianchi, nie wydaje się, by transwestytyzm per se mógl być uznany za przyczynę nieważności małżeństwa ${ }^{47}$, to jednak istnieje kilka tytułów prawnych, z których dany przypadek transwestytyzmu może zostać za taką przyczynę uznany. W jurysprudencji, transwestytyzm klasyfikowany był jako męska anomalia w aspekcie discretio iudicii; uznano bowiem, że możliwy jest przypadek, w którym transwestyta tak dalece odbiega od normy, że cierpi na poważny brak zdolności oceniającej co do istotnych praw i obowiązków małżeńskich ${ }^{48}$. Także „niezdolność do trwalego związku” uznano za przyczynę nieważności małżeństwa transwestyty ${ }^{49}$. Zwykle jednak za tytuły nieważności dla transwestytyzmu przyjmuje się bądź niezdolność do przyjęcia istotnych obowiązków małżeńskich ${ }^{\text {si" }}$, bądź impotencję funkcjonalną̧. Małżeństwo jest nieważne wówczas, gdy osoba dotknięta transwestytyzmem ma tak zaburzoną osobowość, że nie potrafi stworzyć ze wspólmałżonkiem jedności psy-

\footnotetext{
a nawet pojawić się wrzody żołądka. Nieraz małżonka toleruje transwestytyczne skłonności męża pod warunkiem, że nie widuje go w przebraniu. Znany jest fakt, że malżeństwo trwało wiele lat, a żona nie zauważyla objawów transwestytyzmu u wspólmałżonka. Mąż mówił, że idzie odwiedzić przyjaciela, ale udawał się do domu transwestytów, aby się tam przebierać. Po kilku godzinach wracal do domu znów w męskim ubraniu" (Transseksualizm i transwestytyzm. Art. cyt. s. 44).

${ }^{17}$ P. G. Bianchi. Incapacitas assumendi obligationes. Dz. cyt. s. 202.

${ }^{48}$ Por. dec. c. Davino 6.06.1972. SRRD 64:1972 s. 341-345.

19) Dec. c. Pinto 14.04.1975. RRD 67:1975 s. 237. Z poglądem takim nie zgadza się J. Huber, który uważa, że nastapiło tu pomylenie pojęć: „Nierozerwalność jest wedlug kan. 1056 istotnym przymiotem małżeństwa. Nie można jej jednak zaliczać do „obligationes matrimonii essentiales". Gdyby nierozerwalność była istotnym obowiązkiem małżeńskim, wtedy małżeństwo nie byloby nierozerwalne. Obowiązek można bowiem naruszyć. Nierozerwalność jednak oznacza właśnie to, iż prawo nie może zostać naruszone. Jego naruszenia powoduje nieważność. O moralnym obowiązku można powiedzieć, iż jest dozwolony lub niedozwolony. Nie można jednak powiedzieć, że jest nieważny. Wszystko to wskazuje, że nierozerwalność jest jurydyczną normą, a nie moralnym obowiązkiem. Dlatego też nie istnieje ,incapacitas ad perpetuitatem vinculi servandam" (Transseksualizm i transwestytyzm. Art. cyt. s. 47).

${ }^{\text {sn }}$ Dec. c. Giannecchini z 21.02.1995. RRD 87:1995.

"Huber stwierdza, że „osoba z silną skłonnościa do noszenia ubrań płci przeciwnej i ze znacznymi problemami identyfikacji psychoseksualnej może w pojedynczym przypadku być niezdolna do współżycia 2 partnerem (copula perfecta)". Najczęstszym powodem braku tunkcjonowania bodźca erekcji mialaby być niepewność co do płciowej identyfikacji (Transseksualizm i transwestytyzm. Art. cyt. s. 46).
} 
choseksualnej, czyli nie jest zdolna do prawdziwej wspólnoty życia i miłościs .

Niekiedy inne postaci chorób psychoseksualnych przybierają postać transwestytyzmu. Taka pozorna forma owego schorzenia nazwana jest pseudotranswestytyzmem. Stosunkowo często transwestytów myli się z homoseksualistami, bowiem ci ostatni czasem przebierają się w damskie ubrania kierując się intencją zdobycia tych mężczyzn, których w naturalnym męskim stroju nie zdobędą. Kryterium rozróżnienia stanowi współżycie heteroseksualne transwestytów, bowiem pragną oni być uznani przez mężczyzn za kobiety, nie zaś jako pleć męska, która stanowi przedmiot zboczonego popędu homoseksualistów. Ów zamaskowany homoseksualizm jest przyczyną nieważności małżeństwa, ocenianą według zasad odnoszących się do homoseksualizmu ${ }^{53}$.

Pseudotranswestytyzm może być również formą fetyszyzmu. Podniecenie seksualne wynikające $\mathrm{z}$ kontaktu $\mathrm{z}$ całą osobowością partnera heteroseksualnego zostaje wówczas przeniesione na kontakt jedynie z jakąśs częścią tej osobowości albo na przedmiot do niej należący. Najczęściej dotyczy to stroju damskiego, który pobudza seksualnie mężczyznę. W przypadku, gdy mężczyzna może podjąć stosunki małżeńskie tylko wtedy, kiedy nosi strój kobiecy, wówczas wiadome jest, że nie jest on zdolny przekazać nupturientowi prawa do aktu małżeńskiego, który „należy wypełniać w sposób naturalny i normalny"s4.

Jeszcze inną formą pseudotranswestytyzmu może być transseksualizm. Warto poczynić rozróżnienie między tymi dwiema postaciami choroby psychoseksualnej. W przeciwieństwie do transseksualisty, transwestyta na ogól jest zadowolony ze swego ciała. Wszakże transseksualizm i transwestytyzm nie wykluczają się wzajemnie, gdyż ist-

\footnotetext{
${ }^{52}$ Por. dec. c. Pinto 14.04.1975. RRD 67:1975 s. 228-237; dec. c. Di Felice 8.04.1978. DrE 89:1978 f. II s. 18-24; w wyroku c. Giannecchini jednoznacznie opowiedziano się za tym właśnie tytułem niezdolności dla transwestytyzmu: „Incapacitas vero matrimonium contrahendi repetenda est non ex defectu discretionis iudicii, sed ex impossibilitate psychica assumendi obligationes essentiales matrimonii" (Dec. 21.02.1995 - RRD 87:1995 nr 5 s.159). W opinii G. Erlebacha, ów wyrok opisuje transwestytyzm w ujęciu dynamicznym, czyli możliwość stopniowego ujawniania się tej anomalii w czasie małżeństwa wskutek jej rozwoju. Erlebach ukazuje to ujęcie transwestytyzmu na tle ujęcia statycznego, prezentowanego w wyroku c. Burke z 13.06.1991, które tę dewiację seksualną traktuje jako cechę specyficzną seksualności danej osoby dotyczącą jedynie „aktu seksualnego genitalnego” (Tożsamość seksualna. Art. cyt. s. 131-132).

${ }^{5}$ Huber. Transseksualizm i transwestytyzm. Art. cyt. s. 49-50.

${ }^{\lessgtr 4}$ Tamiże s. 51.
} 
nieją różne odcienie i stopnie pośrednie obu schorzeńn ${ }^{55}$. Transwestytyzm jest zaburzeniem umiarkowanym, zaś transseksualizm stanowi poważne zaburzenie osobowości. Stąd potrzeba rozważnie badać każdy przypadek transwestytyzmu, bowiem nie każda forma tego schorzenia powoduje niezdolność osoby do przyjęcia istotnych obowiązków małżeńskich ${ }^{56}$.

\subsubsection{Biseksualizm}

Dewiacja seksualna polegająca na utrzymywaniu relacji seksualnych z mężczyzną i kobietą nazywana jest biseksualizmem. Istnieją znaczne trudności co do jednolitego rozumienia biseksualizmu, jednakże można przyjąć, iż ważnymi czynnikami, które konstytuują to pojęcie są samoświadomość i samookreślenie się konkretnej osoby, jak też jej seksualne zachowanie ${ }^{37}$. W kanonistyce brakuje opracowań dotyczących biseksualizmu, dlatego przy rozważaniu tego zagadnienia trzeba zastosować analogię do problemu homoseksualizmu ${ }^{5 \&}$, który przecież nadal jest bardzo różnorodnie wyjaśniany.

Wplyw biseksualizmu na ważność małżeństwa, a szczególnie na zdolność do wyrażenia konsensu matrymonialnego stanowi szczególny przedmiot podejmowanych rozważań. Nie każda bowiem anomalia psychoseksualna może być przyczyną nieważności małżeństwa. Według P. J. Viladricha, kwalifikacja prawna przyczyn psychicznych nie zależy bowiem od psychopatologicznej natury anomalii seksualnej, ale jedynie od jej ostatecznego skutku, czyli wpływu na zdolność do przyjęcia istotnych obowiązków małżeńskich ${ }^{59}$.

O ile więc między rzeczywistością jurydyczną - niezdolnością do zgody, a rzeczywistością faktyczną - biseksualizmem, zachodzi proporcjonalny związek przyczynowo-skutkowy, wówczas małżenstwo

\footnotetext{
"Brakuje jasnego kryterium rozróżnienia transwestytyzmu od transseksualizmu. W opinii Hubera, czasem transwestytyzm jest etapem wstępnym do transseksualizmu, nierzadko iransseksualista zachowuje się transwestytycznie celem wzbudzenia poczucia lączności z upragniona plcią (Transseksualizm i transwestytyzm. Art. cyt. s. 50).

${ }^{56}$ Huber. Transseksualizm i transwestytyzm. Art. cyt. s. 51.

${ }^{5}$ B. W. Zubert. Biseksualizm a zdolność do zgody małżeńskiej. W: Tożsamość seksualna nupturientów a zdolność do zgody małżeńskiej. Dz. cyt. s. 78-79.

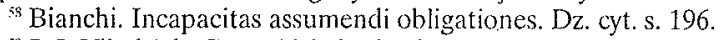

${ }^{\text {so }}$ P. J. Viladrich. Can. 1095. CECDC s. 1246.
} 
może być uznane za nieważne ${ }^{60}$. Wszakże biseksualizm cechować się powinien ciężkością w stopniu powodującym całkowitą dezintegrację osobowości, przenikać całą sferę intelektualną, wolitywną i uczuciową, jak również powinien stanowić sposób zachowania seksualnego $0^{61}$.

Uprzedniość wpływa na znaczenie prawne biseksualizmu, gdyż jeśli schorzenie to istniało już przed zawarciem małżeństwa, związek może być uznany za nieważny ${ }^{62}$. Trwalość omawianej anomalii ma znaczny wplyw na nieważność malżeństwa właśnie w przypadku obowiązku wierności małżeńskiej, bowiem stanowi on małżeńskie zobowiązanie negatywne ${ }^{63}$. Absolutność czy relatywność nie stanowią terminów poprawnych metodologicznie w odniesieniu do biseksualizmu. Można go jedynie klasyfikować jako przyczynę psychiczną powodującą wystarczalność lub niewystarczalność zdolności do przyjęcia istotnych obowiązków malżeńskich ${ }^{64}$.

W orzecznictwie rotalnym biseksualizm zwykle rozpatrywany bywal w kontekście przypadków homoseksualizmu, w których chociaż pośrednio mógł być podstawą zaskarżenia ważności malżeństwa. Jurysprudencja nie miała jednolitego stanowiska w kwestii biseksualizmu. Dewiacja ta uznawana byla za "biseksualną formę homoseksualizmu”, którą można było pogodzić z życiem malżeńskim, albowiem nie pozbawia ona nupturienta zdolności do przyjęcia i urzeczywistnienia przedmiotu zgody ${ }^{65}$. Twierdzono również przeciwnie, że skłonności biseksualnej nie można pogodzić $z$ naturą zgody malżeńskiej, gdyż malżeństwo nie może być dla biseksualistów środkiem terapeutycznym, jako że po pewnym czasie inklinacje biseksualne zwykle stają się dominują$c e^{66}$. We wszystkich sprawach, w których wystąpil biseksualizm podstawą dowodzenia było rozważanie homoseksualizmu już to między mężczyznami ${ }^{67}$ już to między kobietami ${ }^{68}$. W opinii B. W. Zuberta, mi-

"Zubert. Biseksualizm a zdolność. Art. cyt. s. 84.

"Tamże s. 86.

"2 Bianchi. Incapacitas assumendi obligationes. Dz. cyt. s. 199.

${ }^{63}$ Por. F. Castaldi (Rec.). P. Pavanello. Il requisito della perpetuità nell'incapacità di assumere le obbligazioni essenziali nel matrimonio (can. 1095, $3^{\circ}$ ). Roma. Pontificia Università Gregoriana, 1994. W: La Civiltà Cattolica 15/16:1995 s. 320-322.

it Zubert. Biseksualizm a zdolność. Art. cyt. s. 88-89. Por. Viladrich. CECDC s. 1237-1239.

${ }^{63}$ Dec. c. Ewers z 20.01.1973. SRRD 65:1973 s. 33-35 [ 28-35].

(6) Dec. c. Ann z 6.02.1973. SRRD 65:1973 nr 2 s. 64.

${ }^{n 7}$ Por. dec. c. Parisella z 11.05.1978. RRD 70:1978 s. 288-295; dec. c. Huot z 31.01.1980. RRD .72:1980 s. 72-90.

${ }^{8}$ Por. dec. c. De Jorio z 22.03.1980. RRD 72:1980 s. 231-238. 
mo istnienia tytułu psychicznej niezdolności do zgody (kan. 1095, $3^{\circ}$ ), który daje możliwość zaskarżania małżeństwa z jakiejkolwiek przyczyny psychicznej powodującej niezdolność przyjęcia zobowiązań malżeńskich - a zatem również biseksualizmu - w jurysprudencji „ten ostatni nadal nie uchodzi za autonomiczny tytul nieważności małżeństwa" ". Zwykle uznawano go za „homoseksualizm ambiwalentny”"

Poważny biseksualizm, dezintegrujący osobowość uniemożliwia dokonania rozumnej, wolnej i odpowiedzialnej decyzji na malżeństwo i na prowadzenie najglębszej, a zatem wyłącznej i jedynej, intymnej wspólnoty calego życia ${ }^{7}$. Schorzenie to zatem może uczynić osobę niezdolną do przyjęcia obowiązku wierności w małżeństwie.

\subsubsection{Zaburzenia osobowości}

Wymienia się kilka rodzajów zaburzeń osobowości, które czynią osobę niezdolną do przyjęcia m.in. obowiązku wierności. Najczęściej zobowiązania tego nie są w stanie przyjąć nupturienci z osobowością dyssocjalną ${ }^{72}$.

Zachowanie osób dyssocjalnych charakteryzuje się brakiem stałości w postępowaniu $z$ innymi, a szczególnie $w$ relacjach afektywnych i seksualnych $z$ osobami płci przeciwnej. Mężczyźni dotknięci tym zaburzeniem, miewają kontakty seksualne $z$ innymi kobietami przed i po ślubie. Często czują się przymuszeni do ślubu przez nieprzewidzianą ciążę aktualnej partnerki. Rzetelność przyrzeczenia wierności małżeń-

6) Zubert. Biseksualizm a zdolność. Art. cyt. s. 97.

" Por. dec. c. Colagiovanni z 15.03.1983. RRD 75:1983 s. 96-105; dec. c. Giannecchini z 19.07.1983: RRD 75:1983 s. 453-462; dec. c. Stankiewicz z 24.11.1983. RRD 75:1983 s. 675-687; dec. c. Funghini z 19.12.1994, ME 121: 1996 s. 33-57.

${ }^{71}$ Wydaje się, że, zgodnie z sugestią Zuberta, nie potrzeba przykładać miary „tendentio praevalens" do przypadków biseksualizmu, by rozeznać czy to już owo schorzenie czy też jeszcze homoseksualizm. Wystarczy stwierdzić ciężką dezintegrację osobowości, przekreślająca „pełne oddanie osobowe", aby uznać biseksualizm za autonomiczny tytuł niezdolności psychicznej (Biseksualizm a zdolność. Art. cyt. s. 101-102).

${ }^{72}$ Wedle S. Paździora, „w skład tego zaburzenia wchodzi osobowość amoralna, antysocjalna, asocjalna, psychopatyczna, socjopatyczna. Ogólnie ujmując zaburzenie odznacza się dużą niewspótmiernością między zachowaniem a obowiązującymi normami spolecznymi. Osobowość dyssocjalna w jej różnych postaciach należy do tych przejawów dewiacji psychicznych, których dynamika stanowi jedno z najbardziej intrygujących zjawisk badanych przez psychopatologię współczesną" (Przyczyny psychiczne. Dz. cyt. s. 89). Por. J. R. Keating. Sociopatic Personality. Jur 25:1965 s. 429-438. 
skiej trzeba poddać w wątpliwość w konfrontacji z nieuporządkowanym popędem seksualnym ${ }^{73}$. Kobieta o osobowości zaburzonej dyssocjalnie wielokrotnie wchodzi w związki z mężczyznami, które następnie się rozpadają. Wskutek chlodu uczuciowego nie jest ona w stanie nawiązać trwałej więzi międzyosobowej z mężem ${ }^{74}$. Niemoc osoby zaburzonej dyssocjalnie tkwi w obszarze impulsywnego zachowania niezdolności do wytrwania i zachowania obowiązku w sumieniu, nie zaś w percepcji czy pojmowaniu ${ }^{75}$.

Osobowość schizoidalna stanowi inny typ zaburzeń osobowości mogących uniemożliwić przyjęcie obowiązku wierności w małżeństwie. Istotą tego zaburzenia jest brak syntonii, czyli zakłócenie współodczuwania $\mathrm{z}$ innymi ludźmi. Życie w świecie własnych tylko przeżyć psychicznych powoduje izolację psychiczną, co prowadzić może do niewielkich lub nawet żadnych bezpośrednich kontaktów uczuciowych z drugim człowiekiem. Pożycie małżeńskie może być przez taką osobę intelektualnie pojęte jako obowiązek przymierza sakramentalnego, lecz czlowiek ten przeżywa wszelkie odniesienia seksualne bez emocjonalnego zaangażowania ${ }^{76}$. W centrum uwagi osoba taka stawia swoje problemy i przeżycia, wskutek czego zaniedbuje swoje obowiązki, jak również lekceważy obowiązujące normy dopuszczając się licznych zdrad ${ }^{77}$.

Obowiązek wierności może także okazać się niemożliwy do przekazania w konsensie małżeńskim wyrażanym przez ludzi o osobowości paranoicznej. Zaburzenie to charakteryzuje się rozpadem osobowości, w którym osoba doświadcza omamów (,spostrzega" bez bodźca wewnętrznego), pseudohalucynacji słuchowych oraz urojeń, zwłaszcza prześladowczych. Człowiek z osobowością paranoiczną ma przeświadczenie o rzekomych ukrytych i nieuczciwych intencjach innych ludzi, co powoduje podejrzliwość i agresję wobec różnych zachowań ludzkich. Uważa się, że owa nadmierna podejrzliwość, mogąca objawiać się także w bezpodstawnym podejrzewaniu wspólmałżonka o zdrady

\footnotetext{
${ }^{73}$ Paździor. Przyczyny psychiczne. Dz. cyt. s. 95.

${ }^{73}$ Paździor. Przyczyny psychiczne. Dz. cyt. s. 99.

${ }^{73}$ Bianchi. Incapacitas assumendi obligationes. Dz. cyt. s. 240.

${ }^{76}$ Tamże s. 251.

${ }^{n}$ Paździor podaje przykład pewnego mężczyzny, który ,zakochany w muzyce, martwych przedmiotach oraz samotności, byl niesłowny i kłamliwy. Przejawiał nadmierną skłonność do kobiet. Po ślubie wyrazit się do żony, że byla osiemdziesiąta z rzędu" (Przyczyny psychiczne. 'Dz. cyt. s. 100-101).
} 
mał̇żeńskie już wkrótce po zawarciu małżeństwa, poważnie przeszkadza w nawiązaniu relacji interpersonalnych ${ }^{78}$. Niejednokrotnie może też okazać się swego rodzaju kamuflażem osłaniającym niewierność małżeńską czlowieka o osobowości paranoicznej ${ }^{79}$. Osoba taka nie może ważnie zawrzeć przymierza małżeńskiego, gdyż nie jest zdolna do przekazania w nim obowiązku wierności.

Pośród zaburzeń osobowości uniezdalniających do zachowania wierności należy wymienić także typ osobowości chwiejnej emocjonalnie. Niestabilność uczuciowa, objawiająca się zamąconym obrazem samego siebie, własnych celów, a nawet preferencji seksualnych, charakteryzuje się przede wszystkim zmiennością nastrojów, które zwykle oscylują wokól gniewu, niezadowolenia, pustki i osamotnienia. Budowanie relacji międzyosobowych sprawia czlowiekowi chwiejnemu emocjonalnie wielką trudność. Nie widzi on bowiem dobra współmalżonka czy potomstwa zatrzymując się na wlasnych potrzebach. Nieuporządkowanie sfery seksualnej u osoby o takim typie zaburzonej osobowości może uczynić ją niezdolną do przekazania przedmiotu zgody małżeńskiej, jakim jest wiernośćcin.

Wypada również wspomnieć o osobowości histrionicznej (histerycznej) jako moźliwej przyczynie nieważności małżeństwa. Człowiek z cechami takiej osobowości może przejawiać m.in. postawę uwodzicielską, pozbawioną bądź głębi związków uczuciowych bądź lojalności wobec licznych partnerów, a często jednego i drugiego. Kobiety $z$ osobowością histrioniczną w krótkim czasie po zawarciu malżeństwa są w stanie nawiązać bliskie kontakty $z$ innymi mężczyznami, dopuszczając się zdrad. przez co nie mogą podjąć istotnego obowiązku jedności ${ }^{81}$.

\footnotetext{
${ }^{78}$ Bianchi. Dz. cyt. s. 248.

${ }^{7 y}$ Ilustracją takiej postawy towarzyszącej zaburzonej osobowości typu paranoicznego może być przypadek mężczyzny, który był chorobliwie zazdrosny. Według własnych zapewnień, z powodu zazdrości, chciał sobie odebrać życie. To jednak nie przeszkadzato mu dopuszczać się zdrad małżeńskich, czego widomym znakiem było nieślubne dziecko (Paździor. Przyczyny psychiczne. Dz. cyt. s. 104).

s" Przykładem tego typu zaburzenia jest przypadek mężczyzny, który „podejmując wspólżycie seksualne z przyszłą żoną, współżył również z innymi dziewczynami, działał u niego silny popęd seksualny. W trakcie malżeństwa, jak zeznali świadkowie, «skakal z kwiatka na kwiatek»” (Paździor. Przyczyny psychiczne. Dz. cyt. s. 106-107).

"Paździor przedstawił przypadek kobiety, która „po zawarciu małżeñstwa twierdzila, że będzie robić to, co jej się podoba. Flirtowała z mężczyznami, nie interesowała się domem, więcej była zajęta psem, papugami aniżeli mężem" (Przyczyny psychiczne. Dz. cyt. s. 112).
} 


\section{Podsumowanie}

Niezdolność psychiczna do przyjęcia istotnych obowiązków małżenskich służących jedności i prokreacji jest wadą konsensu małżeńskiego powodującą jego nieważność (kan. 1095, $3^{\circ}$ ). Istotą wady jest brak przyjęcia obowiązku pożycia intymnego bądź obowiązku wierności małżeńskiej. Przyczyny niezdolności stanowią zaburzenia sfery psychoseksualnej bądź osobowościowej. Homoseksualizm, transseksualizm (gdy występują w postaciach ciężkich i uprzednich) albo osobowość histeryczna mogą przyczynić się do niezdolności przyjęcia obowiązku do aktu małżeńskiego. Niezdolność do przyjęcia obowiązku wierności małżeńskiej może zostać spowodowana przez hiperseksualizm (nimfomanię lub satyryzm), transwestytyzm, biseksualizm albo zaburzenia osobowości takie jak osobowość dyssocjalna, schizoidalna, paranoiczna, chwiejna emocjonalnie czy histeryczna.

Powyższe przypadki perturbacji psychoseksualnych i osobowościowych mogą uniemożliwić zawarcie ważnego przymierza małżeńskiego. Wspólnota życia i miłości potrzebuje bowiem fundamentu praw i obowiązków. Pośród nich szczególnie istotne miejsce zajmuje prawo do pożycia intymnego oraz prawo do wierności małżeńskiej.

La caretteristica giuridica di incapacitá psichica di assumere gli obblighi essenzial matrimoniali che servono all' unita' e alla procreazione (con. 1095 a. $3 \mathrm{CIC}$ )

\section{Sommario}

L'incapacità psichica di assumere gli essenziali obligazioni matrimoniali, che servono alla unità e procreazione è il difetto del consenso matrimoniale, che determina la sua invalidità. In realtà, si tratta di una carenza della trassmisione e dell'accoglienza sia il dovere dell'atto coniugale sia il dovere della fedeltà matrimoniale. Ci sono le cause della incapacità nel campo di disfunzioni psichosessuali oppure di perturbazioni della personalità. Comossesualità, il trassesualismo (se si presenta come forma grave e precedente) o personalità isterica possono contribuire incapacità di assumere di dovere dell'atto coniugale. Incapacità di assumere di dovere della fedeltà puo essere determinata dal ipersessualismo (nimfomania o satirismo), trasvestitismo, bisessualismo oppure disfuzioni del personalità come personalità dissociale, schizoidale, paranoidale, instabile emozionale sia isterica.

I sopradetti casi dei disfunzioni psichosessuali e della personalità possono impedire l'alleanza matrimoniale. La comunità della vita e amore ha bisogno di fondamento di diritti e doveri. Il particolare posto fra di loro prende il diritto al'atto coniugale e anche il diritto alla fedeltà matrimoniale. 